\title{
A Bubble in the Vein: Suicide, Community, and the Rejection of Neoliberalism in Hanya Yanagihara's A Little Life and Miriam Toews's All My Puny Sorrows
}

\author{
Amy Rushton
}

This chapter discusses how contemporary fiction opens up new ways of understanding suicidal depression, not only as symptomatic of an unsustainable neoliberal worldview but also as offering critiques of, and possibilities of resistance to, neoliberal logics of success. Both Hanya Yanagihara's A Little Life (2015: hereafter ALL) and All My Puny Sorrows by Miriam Toews (2014: AMPS) feature narratives that disconcert the reader: Yanagihara's second novel has been criticized for its melodramatic elements, whilst AMPS continues Toews's autofictional insertion of her immediate family's tragic experiences with suicidal depression. Rather than viewing such formal choices as self-indulgent or naval gazing, I argue that these fictional explorations of suicidal depression and, crucially, the community around individuals who wish to no longer live can be interpreted as a protest against neoliberalism's placatory myths of the individ-

\footnotetext{
A. Rushton ( $\square)$

Nottingham Trent University, Nottingham, UK e-mail: amy.rushton@ntu.ac.uk

(C) The Author(s) 2019

S. Deckard, S. Shapiro (eds.), World Literature, Neoliberalism, and the Culture of Discontent, New Comparisons in World Literature, https://doi.org/10.1007/978-3-030-05441-0_9
}

195 
ual and the attainment of personal 'success' (what Oliver James refers to as neoliberalism's characteristic of "selfish capitalism": 2007, 2008). Rather than distressing, I read both $A L L$ and $A M P S$ as narratives that disconcert neoliberal values and assert their discontent with unsustainable ideals. Instead of being at the mercy of an inhumane world and unsupportive institutions, these fictional narratives dramatize the productively disruptive potential of depression.

It is my contention that fictional narratives of suicidal depression can disrupt neoliberal approaches to wellbeing: whereas nonfictional narratives of severe, chronic, and suicidal depression are structurally bound to expectations of progress and recovery, fictional narratives are not bound to such structural predictability - it is, to use Russian Formalist terms, a story without a plot. Indeed, $A L L$ and $A M P S$ are disturbing narratives due to their depiction of suicide as, ultimately, rational. It is entirely possible that AMPS and ALL cannot allow for a 'happy ending' because such an outcome seems impossible under current societal and institutional conditions. Yet neither novel isolates the distressed individual at the heart of their narratives. In fact, both frame the suicidal individual through the perspective of their familial community: AMPS is narrated entirely by Yoli and develops her empathy with her sister's desire to die, whilst $A L L$ frequently views Jude through the perspectives of Willem (his closest friend) and Harold (his mentor and later adoptive father). Inevitably, the emphasis on community is at odds with the neoliberal fixation on individualism and demands for self-responsibility: both novels make it clear that individualism is a convenient yet morally bankrupt dumping ground for responsibility, instead offering community and radical empathy as strategies of resistance to an inhumane and irresponsible neoliberal society.

When published in the United Kingdom, the United States, and Canada, AMPS and $A L L$ caught the attention of literary press and awards panels. Both novels portray the agonized turmoil of central characters who increasingly see continuing to live as unbearable and yet live in a social milieu where suicide is unconscionable-both legally and within their familial communities. Yanagihara's second novel was much discussed in literary conversation online and on podcasts, eventually ending up as a shortlisted title on major literary prizes in the United States and Britain (the 2015 National Book Award in Fiction and the Man Booker Prize for fiction, respectively). ALL follows four friends in New York-Willem, JB, Malcolm, and Jude-from their dorm-room days at university through to their late-middle age. As the narrative proceeds, it increasingly focuses on 
Jude, whose tragic childhood and adolescence of shocking emotional, physical, and sexual abuse is slowly revealed to the reader through his memories. Yanagihara's novel provides detailed descriptions of Jude's inner anguish and self-hatred, which manifests itself in lifelong self-harm. After a few incidents where his self-harm tips into suicide attempts, Jude eventually kills himself at the age of 56 (Yanagihara 2015: 717). Far from universally lauded, $A L L$ provoked extreme responses; readers and critics seemed either to love or hate the novel's length, its seemingly overwrought or melodramatic style, its lack of historical context, and especially its depiction of abuse and self-violence. Alex Preston's review is a neat summation of the discomfiture experienced by readers, stating that there is "something chillingly relentless about the way that Yanagihara subjects the reader to Jude's suffering. It is unremitting and it is ghastly, and I had to put the book down several times when I was reading it" (Preston 2015). Such a notion of 'too much' and of physically abandoning the novel are common experiences for those who detest or love $A L L$, an affective response I will discuss in the latter part of this chapter.

Whilst by no means as attention grabbing and polarizing as Yanagihara's novel, All My Puny Sorrows was similarly lauded (winning two major Canadian literary prizes, as well as shortlisted for the Wellcome Book Prize in Britain) and received with some critical bafflement over its tragicomic portrayal of psychological suffering and suicidal depression. AMPS recounts the relationship between two sisters in Canada from the point of view of the younger sister: Yoli's narration carries the reader through the last few months of her elder sister's life, Elf, a celebrated pianist who is funny, intelligent, beautiful-and suicidally depressed. After multiple attempts to end her own life throughout her adulthood, Elf finally succeeds by jumping in front of a train, a method that the sisters' father also chose (Toews 2014: 48). AMPS is Miriam Toews's sixth novel and one that continues her arguably auto-fictional style: throughout her career thus far, Toews often draws inspiration from her childhood and adolescence in the Mennonite community in Canada, as well as her immediate family's tragic history with suicidal depression. Toews's father and elder sister both killed themselves and AMPS draws heavily on events leading up to the suicide of her only sibling, Marjorie, in 2010. The tragic circumstances around Toews's family could be a source of morbid fascination or a reason to avoid reading her fictionalized narratives of her experience with suicidal loved ones. The latter was certainly true for me: the idea of reading a novel based so heavily on watching a sibling watch their sister 
repeatedly attempt suicide, and knowing the outcome, was 'too much' to contemplate. What changed my mind was also the quality that many critics noticed about AMPS: its tragicomic and empathetic tone.

On its publication, Stevie Davis noted that the novel's "compulsive readability is all the more remarkable since the story issues from such a dark place in the author's heart. [...] Starvation, pills, slitting her wrists, drinking bleach: none of this is remotely funny. Nevertheless, as I read, I laughed aloud even as tears rose in my eyes" (Davis 2014). Make no mistake, however: AMPS is not simply a touching comedy of mourning. Reading AMPS, one is struck that the 'dark place' in Toews's heart is not simply a space of grief but of righteous anger at a system and society that could not help her sister in any meaningful, long-lasting way. Undoubtedly, these are novels that are difficult to read at times. However, I argue that both are providing provocative contemporary narratives of mental health. ALL and AMPS both question the ethics of survival at all costs and add an empathetic viewpoint on debates about the right to die for those suffering psychological distress. Specifically, I read these novels as contesting the impact of neoliberal logic-ideological and economic logic-regarding ideas of what constitutes "good" mental health and treatment.

Since the 1970s, neoliberalism has been the dominant economic view of those nations which exert the greatest influence across the globe (Chang 2014: 69). As the character of capitalist accumulation significantly shifted from the 1970s onwards-coinciding with the rise of neoliberal policy and praxis-I view neoliberalism as the latest, possibly final, chapter in the overarching, ongoing historical process of capitalism (Harvey 1989: 39-65, 170-72; Arrighi 1994: 1-6, 16-23). Currently the dominant hegemonic force within the capitalist world-system, neoliberalism has been the central ideology and economic justification for policies concerning mental health in Europe and North America, policies that arguably are not as interested in the wellbeing of a mass populace as they would like to appear. Ultimately serving the interest of the globe's wealthy elite, neoliberalism is no mere economic theory: neoliberalism is best understood as hegemonic ideology, "an ongoing attempt to mobilize a particular set of ideas and governmental practices $[\ldots]$ in the pursuit of a particular set of interests, neutralising and forestalling the emergence of political threats to this endeavour" - the "particular set of interests" being the retrenchment of elite power (Gilbert 2013: 18). To further protect and serve its interests in fostering inequality, neoliberalism handily perpetuates a view of human nature as atavistic. Such a view of humanity as utterly self-interested in accumulating status and capital inevitably means that neoliberalism is 
largely unconcerned with collective responsibility, least of all matters of structural inequality. The reciprocity between cultural ideology and economic praxis creates a sustaining framework for neoliberalism, presenting its entrenched ideology as if it is a universal and predetermined system of thought and government. As such, "neoliberal habits and styles of thought" present themselves as "operat[ing] spontaneously as a kind of common sense and institutionally as a mode of governmentality" (Gilroy 2013: 24). The false 'common sense' rationality of neoliberalism provides the justification for institutions to distance themselves from concerns over structural inequality, thus accentuating how capitalist success is achieved at the expense of other people. The emphasis on individual responsibility helps neoliberalism to ignore its wider structural responsibility: in a neoliberal world, failure (such as unhappiness or severe distress) "is just a consequence of a bad attitude rather than structural conditions" such as "the titled scales of race, class, and gender" (Halberstam 2011: 3). Neoliberal ideology is dangerous due to its fundamentally irresponsible, unaccountable nature. Far from being the rational, detached, and neutral discourse it purports to be, neoliberalism deliberately overlooks its longterm impact on individuals and communities.

Neoliberalism's refusal of responsibility is symptomatic of its theoretical insistence on non-interference by the state, but the theory and practice of neoliberalism means the ideology is inherently contradictory. Although neoliberalism advocates a separation between state and society, in practice the neoliberal state will endeavour to interfere with society, normally for economic advantage. Hence, I am sceptical of the recent interest in mental health concerns conveyed by mainstream political discourse on both sides of the Atlantic. The efforts to destigmatize experiences of mental health issues such as (but not limited to) depression, anxiety, self-harm, and suicidal behaviour have led to calls for more provisions in workplaces, schools, and universities - at a time of economic recession and mass cuts to public services including health care. Such a rise in discussion could be seen as a response to such cuts; however, politicians have, somewhat suspiciously, embraced the concerns around mental health provisions. UK Prime Minister Theresa May's second-term promises include the prioritising of mental health services - albeit without pledging more money, stating that "it is always wrong for people to assume that the only answer to these issues is about funding" (Stone 2017: n.p.). Instead, May insists that it is stigma rather than a lack of funding at the heart of problems with mental health services (Ibid). Arguably, the discussions around destigmatizing 
mental health are so prevalent that it would be impossible or foolish for those in power to ignore or suppress. However, I follow the lead of those who note that neoliberal policies have a vested interest in mental health due to economic necessity. May's notion that stigma can be divorced from mental health provisions is contradicted by Dominic Sisti, a behavioural health care specialist in the US. Sisti suggests that the stigma around mental health is perpetuated by economic concerns over "high-cost patients who maybe are difficult to treat or noncompliant" so "actually emerges out of [the US] health care system more than from the public" (Raphelson 2017: n.p.). Such stereotyping of mental health patients as burdensome is firmly located within neoliberal ideology: as Elise Klein notes, "neoliberalism reduces subjectivity to that of the rational, self-sufficient, economic actor," so it is therefore vital that "individuals are able to freely conduct themselves in relation to economic efficiency and effectiveness"-meaning that any psychological conditions which prevent such efficiency and effectiveness must be addressed (Klein 2017: 52-53). Neoliberalism needs to look after its economic actors, and therefore it is not surprising that May announced that the current UK government's plan is to tackle mental health "not in our hospitals, but in our classrooms, at work and in our communities" (Stone 2017: n.p.). In other words, to further increase the distance between mental health issues and state responsibility. ${ }^{1}$

As economic and social policy turned towards neoliberalism throughout the twentieth century, its particular interests in decoupling welfare from state responsibility and rampant individualism have arguably influenced the pathologizing and treatment of mental health. The focus on the individual and self-responsibility has been absorbed into European and American psychiatric practice and psychological models, with the earlier scientific-rationalist approach (although problematic in itself) steadily transforming into "moralising critiques of individual development" (Smail 2005: 10). By the second half of the twentieth century, "the emphasis was always on what the individual should do to overcome or compensate for personal inadequacies" rather than "considering the material circumstances of people's lives" (Ibid). David Smail, an NHS psychologist whose life's work was spent advocating for a social materialist model of clinical psychology, readily connects the move towards these self-responsible psychological models with the rise of neoliberal policies and ideologies. Indeed, Smail argues that the privileging of self-responsibility is core to psychology's "suppression of the social," making it nigh-on impossible "to conceive of responsibility as anything other than the application of 
personal influence which has its origin entirely within the individual agent" (Smail 2005: 75). Such an onus on responsibility lying entirely with the individual benefits those in power (not necessarily politicians but those they ultimately serve, the beneficiaries of the capitalist world-system), for it "is the feeling of responsibility (conscience) that the powerful seek to exploit in others in order to divert attention from the actual (distal) causes of their discomfort" (Smail 2005: 77).

In the history of depression as an identifiable condition in Europe and North America, Ann Cvetkovich notes that its construction as a "treatable disease" has largely disregarded any suggestion of social and cultural readings, "especially in the context of the practical urgencies of treatment and new pharmacological discoveries" (Cvetkovich 2012: 90). It is this medical model that is commonly replicated in mainstream culture-not just political but also in literary, cinematic, and televisual narratives (Ibid). Cvetkovich notes that the pathologizing of depression has a twin appeal: depression is framed as a manageable "disease that can be detected, diagnosed, and treated," yet such a "model based on biology relieves people of individual blame or responsibility" (Cvetkovich 2012: 90-91). ALL and AMPS are exceptional, then, in their dramatization of suicidal depression: whilst they depict the pathologization of depression and the emphasis on self-responsibility for one's life (or suffering), these novels also critique the societal problems that deepen severe depression as well as gesture to the absence of a meaningful way to live in a neoliberal world.

Before turning to how $A L L$ and $A M P S$ problematize neoliberalism via the depressive perspective, it is important to understand how neoliberal ideology also informs the character of mental health conditions, such as depression - or at least how depression is read within a particular historical moment. We can read states-of-mind like depression as an affective response to the unsustainable logic of neoliberal capitalism; after all, depression is a term applied to severe economic downturn. Less flippantly, China Mills forcibly contends that neoliberal society has a very real, direct impact on psychological wellbeing across the globe:

the distress caused by a neoliberal rationale of [economic] reforms and inequality is mediated through a bio-psychiatric lens as 'illness', opening up interventions that are individual and often pharmaceutical and that are, thus, part of the same neoliberal rationality as that which may have caused distress initially. (Mills 2014: 50) 
Thus, our contemporary understanding of depression is caught in a vicious cycle of neoliberal rationality, policy, "big pharma," and inequality. How is one ever meant to escape? Such a question suggests that neoliberalism has an interest in overcoming mental distress; the truth is that a neoliberal economic order benefits from the depressive condition. Cvetkovich views depression as not only an "affective register" of societal discontent but also "one that often keeps people silent, weary and too numb to really notice the sources of their unhappiness" (Cvetkovich 2012: 12, my emphasis). The typical characteristics of depression-silent, weary, and numb-are perfect conditions for the perpetuation of neoliberalism. Contemporary depressive subjects struggle to see the reasons for their unhappiness or distress beyond themselves; messages reinforced by a neoliberal society and bio-psychiatric model tell us that the fault lies within us and not to look beyond ourselves. Yet mental health issues are not simply responses to an irresponsible and inhumane neoliberal worldview: depression and suicidal depression also reveal neoliberalism's unsustainability. If depression can be read as symptomatic of neoliberalism, then AMPS and $A L L$ also enact a critique of the neoliberal, pathological cycle.

A common element of the neoliberal model of mental health is the artificially moral emphasis on self-responsibility; failure to recover inevitably means "personal failure: either a moral failure of will (refusal to take responsibility) or falling short as a human being" (Smail 2005: 10-11). However, it is notable that both Jude and Elf are presented as exceptionally talented individuals whose struggles very rarely impact their professional lives in corporate law and classical music, respectively. One of the ironies shared by both novels is that Jude and Elf are viewed as highly successful individuals in the public sphere-and a privileged, uppermiddle-class, bourgeois sphere at that. Both are famous and respected in their professions, with careers going from strength to strength, are beloved by colleagues and acquaintances, socially popular, physically attractive, and highly intelligent. Jude is self-conscious of his physical disability (his legs are permanently injured after a horrific attack as a teenager) but it is apparent that no-one in his professional world perceives his cane and later wheelchair as anything that lessens his power: "In his life at the firm, he was assessed only by the business he secured, by the work he did: there, [...] he felt at his most human, his most dignified and invulnerable" (Yanagihara 2015: 501, 502). Similarly, there are references throughout AMPS of Elf being "saved," transported, or at least kept sane by her concert performances (Toews 2014: 25, 60, 303). And yet successful careers 
and their attendant wealth are not reason enough to keep their suicidal feelings at bay, flying in the face of neoliberal logics of success. Instead, $A M P S$ and $A L L$ show the tragic lack of a meaningful answer to the question of why Elf and Jude need to stay alive.

Neither novel affirms that "it gets better"; it is clear that Elf and Jude are always spiralling towards their next suicide attempt. For all the black humour and sadness of AMPS and the graphic depiction of self-harm and memories of relentless horror in $A L L$, it is the inevitability of their deaths that is probably the most upsetting and discomforting element of both. At the time of $A L L$ 's publication, I read and heard readers expressing anger, disgust even, that Yanagihara ends with Jude's inability to 'get over' his trauma and eventual suicide. This is why AMPS makes a useful companion piece to $A L L$ : whereas $A L L$ concerns itself with suicidal depression as a consequence of trauma and PTSD, AMPS recounts a similar, inevitable decline towards a completed suicide with flashbacks to Elf's early life and young adulthood. Although frustrated by life in their somewhat isolated, patriarchal, Mennonite community, Yoli's memories show Elf as a capricious teenager, spirited although prone to solemn reflection and sombre moods. There is no triggering event in Elf's life; Yoli, and thus the novel, makes no attempt to offer an explanation for her suicidal depression. Elf is a chronic depressive whose severe depression has plummeted to increasing cycles of suicidal behaviour. From the novel's beginning, Yoli knows that there is more chance of Elf killing herself than of her recovering. Elf and her family have no idea what form recovery could even take. The angry heart of Toews's novel is that the medical and legal worlds demand that Elf remains alive but offer no narrative about how her life can be made worthwhile.

Whereas $A L L$ steers away from implicating institutions due to Jude's extreme privacy regarding his past and his health, AMPS directly tackles the contradictory emphasis on self-responsibility for high-risk patients in the Canadian mental health system. In an interview, Toews describes how her family's experience drove the representation of Elf's hospitalization: "I had so much anger towards the mental health system in Canada, the cruelty of it, the way patients are treated, infantilized, it almost seems criminalized. It was burning a hole in my heart and mind" (O'Keefe 2015: n.p.). The anger in AMPS stems from frustration of institutions which demand that Elf remains alive at any cost-as long as that cost falls under that year's budget for mental health care. AMPS lays bare the cyclical realities of psychiatric care: the always understaffed wards with their seemingly 
endless rotation of nurses, the disinterested consultants, and the exhausted family at the centre. Elf's immediate family-Yoli, their mother, Elf's husband-carry the burden of watching her as the nursing staff change rotation too frequently to keep a consistent watch on Elf's movements. Yet as the novel continues, the focus of Yoli's anger increasingly aligns with Elf's anger at not being offered any concrete, meaningful reason to continue living as a suicidally depressive person. All the treatments she is offered are merely band-aids that inevitably peel and fall away, so that the suicidal cycle begins again:

We were trying to assemble a team of caregivers who would work with Elf when she was released from the hospital. [...] What would this team do with her? she asked. What would Elf do with the team? Make lists? Set goals? Embrace life? Start a journal? Turn that frown upside down? She kept unearthing huge fundamental problems with the whole concept. [...] Elf was up in arms, gnashing her teeth against the smarmy self-help racket that existed only to sell books and anaesthetize the vulnerable and allow the socalled "helping" profession to bask in self-congratulation for having done what they could. They'd make lists! They'd set goals! They'd encourage their patients to do one "fun" thing a day! (Oh you should have heard the derision in Elf's voice when she said the word fun like she'd just spit out the word Eichmann or Mengele.) (Toews 2014: 49-50)

Whereas her family needs to cling to these ultimately short-term solutions to suicidal depression in the hope that something will keep Elf alive, Elf has no such illusions. But as AMPS reaches its conclusion, Yoli has begun to grasp Elf's perspective on suicide as she wrestles with the ethical and legal possibilities of helping Elf to end her life: after another attempt, Elf asks Yoli to help her to get to Zurich so that she can undertake assisted suicide (Toews 2014: 88, 90). Initially horrified, Yoli begins to contemplate what it means that her sister would ask for such assistance:

Did Elf have a terminal illness? Was she cursed genetically from day one to want to die? Was every seemingly happy moment from her past, every smile, every song, every heartfelt hug and laugh and exuberant fist-pump and triumph, just a temporary detour from her innate longing for release and oblivion? (Toews 2014: 90).

Elf asking Yoli to take her to Switzerland to die is the turning point for Yoli: after years of tearfully, furiously, bullyingly imploring her elder sister 
to stay alive, she seems to comprehend how exhausted Elf is by continuing to live. Unfortunately, such a realization does not come to Jude's family until after his death. Late in $A L L$, Harold painfully reflects "how hard it is to keep alive someone who doesn't want to stay alive":

First you try logic (You have so much to live for), and then you try guilt (You owe me), and then you try anger, and threats, and pleading ( I'm old; don't do this to an old man). But then, once they agree, it is necessary that you, the cajoler, move into the realm of self-deception, because you can see that it is costing them, you can see how much they don't want to be here, you can see that the mere act of existing is depleting for them, and then you have to tell yourself every day: I am doing the right thing. (Yanagihara 2015: 709-710, 717; emphasis in original)

Harold's realization is excruciatingly painful, more so than the news that Jude has indeed finally succeeded in killing himself. Harold's self-deception does not save him or Jude from pain; if anything, it adds to both their suffering. The narrative perspectives of Yoli in earlier parts of AMPS and Harold in $A L L$ reflect an observation by David A. Karp: in his study of caregivers for individuals with mental health issues, Karp notes that although family are aware that "they have no control over mental illness," such an awareness still "does not insulate caregivers from experiencing suicide attempts as a rejection of their love" (2001: 187). As such, although hard-won and still enormously painful, Yoli's shift in perspective shows the ethical value in reading suicide from the perspective of those who wish to die. Of course, Yoli does not want her sister to die-but she recognizes that society offers Elf no meaningfulalternative. And here we hit upon the resistant potential of suicidal depression in these fictional narratives.

In $A L L$ and AMPS, suicidal depression shows the depressed subject and the reader what is absent in society-a meaningful narrative beyond neoliberal capitalist expectations of individualism and "personal" success, including career, wealth, private property, biogenetic affinity, and heteronormative family structures. Disability scholar Dan Goodley observes that "an individualized view of maladaptive behaviour ignores the possibility that such behaviour constitutes rational and resistant reactions to maladaptive environments" (Goodley 2001: 215; my emphasis). Mills posits that it might be possible to read suicides "as responses to social inequalities and economic reforms in different contexts," so that self-harm and even suicide can be understood as "psychopolitically" meaningful (Mills 
2014: 38-39). That is, suicide and self-harm may be entirely rational and resistant reactions to an increasingly inhumane neoliberal social order. In these novels, severe depression is a condition which responds to something missing in society, not in the individuals. For Jude and Elf, the lack of a meaningful narrative beyond their immediate experiences points to what is lacking, what is absent.

An absence of a meaningful narrative for living is not inherently a nihilistic perspective; it is important to remember the role absence plays in utopian thinking. This is not to suggest that suicide is a utopian act, at least not in the abstract sense: in other words, utopia is not to be understood as an imaginary dreamland in the realm of the "fantastic and compensatory" but as something we know to be lacking, something that indicates unrealized potential not yet available to us (Levitas 1990: 15). According to Ernst Bloch, in order to be socially and politically useful, the utopian function needs to be grounded in recognition of the possible (concrete utopia), must exhibit "militant optimism" and educated hope (docta spes), and, crucially, is anticipatory ("Not Yet") (Bloch 1986: 137, 146-47). Crucial for Bloch's understanding of utopian thinking is its emphasis on possibility, thus confronting the reasons that make the production of utopia so difficult. Bloch stresses that hope is vital in thinking about utopia, not a passive strain of thinking positively:

Hope is critical and can be disappointed. [...] Hope is not confidence. Hope is surrounded by dangers, and is the consciousness of danger and at the same time the determined negation of that which continually makes the opposite of the hoped-for object possible'. (Bloch 1988: 17).

This understanding of hope is one of tough optimism. It is to have faith in a future that you cannot foresee. As such, utopian thought is wilful and committed, not simply wishful and purely optimistic. Such Blochian hardfought optimism is a perspective that Jude identifies with: earlier in the novel, the narrative reveals that Jude thinks of himself as "an optimist":

Every month, every week, he chose to open his eyes, to live another day in the world. [...] He did it when he was so exhausted of trying, when being awake and alive demanded such energy that he had to lie in bed thinking of reasons to get up and try again. (Yanagihara 2015: 143-144)

Of course, as his life goes on, it becomes increasingly harder for Jude to justify continuing to live. Yet this moment in $A L L$ flags up the simultane- 
ous utopian impulse of the suicidal depressive: suicidal thoughts can contain a wish for absence-to absent oneself from a life without a meaning-and optimism for the future. The future will either fulfil the desire for absence (completed suicide) or a renewed attempt to continue living. Both acts can only be achieved by having faith in the future, that the next moments in time will bring relief, rather than impasse. The strangely utopian impulse of suicidal depression, then, is why the denial of death is so damaging to Jude and Elf: both know that they can end their suffering. The problem is that societal expectations will not allow them to do so, yet offer no long-term alternative to their suffering. As Cvetkovich observes, this short-sightedness creates a sense of impasse, of feeling stuck, suggesting "that things will not move forward due to circumstance - not that they can't, but that the world is not designed to make it happen or there has been a failure of imagination" (Cvetkovich 2012: 20; my emphasis). Neoliberalism's relentless presentism and rejection of collective responsibility is at odds with the need to imagine a better future, an imaginative act that the suicidally depressive subject requires. In other words, neoliberal ideology and praxis have no scope for utopian thinking.

If neoliberal society offers no meaningful, imaginative narrative beyond its narrow confines of personal attainment and self-responsibility, then it is important to ask what does prevent Elf and Jude from delaying their inevitable acts of suicide. Of course, society demands that they stay alive but their exhaustion and increasing withdrawal demonstrate that societal demands are not justification enough. Something else is tethering them to life: their feelings of responsibility to others, chiefly, their familial communities. Towards the end of his life, Jude reflects that although he has never believed his life to be meaningful, he recognizes that if his family and friends "wanted him to stay alive, then he would"; "He hadn't understood why they wanted him to stay alive, only that they had, and so he had done it" (Yanagihara 2015: 686-688). Although not immediately obvious, the very title of Toews's novel is an acknowledgment of the important role of familial bonds: AMPS is derived from an acronym that a teenage Elf uses as a graffiti tag around Winnipeg:

She came up with a design that incorporated her initials E.V.R. (Elfrieda Von Riesen) and below those the initials A.M.P. Then, like a coiled snake, the letter $S$ which covered, underlined and dissected the other letters [...]. $[T]$ he A.M.P. stands for All My Puny... then the big $S$ stands for Sorrows which encloses all the other letters[...]. (Toews 2014: 8, 10) 
The significance of "sorrow" dominating the design is perhaps too obvious: Elf's sorrow is what overwhelms her sense of self, even her love of and talent for music. What is less obvious is the origin of Elf's tag: Yoli recalls Elf telling her that the phrase "all my puny sorrows" is taken from "To A Friend, With An Unfinished Poem" by Samuel Taylor Coleridge (1794), a poem the adult Yoli later finds when browsing their mother's bookshelves:

I too a SISTER had, an only Sister-

She lov'd me dearly, and I doted on her!

To her I pour'd forth all my puny sorrows

(As a sick Patient in his Nurse's arms)

And of the heart those hidden maladies

That shrink asham'd from even Friendship's eye. (quoted in Toews 2014: 237)

Elf's choice is an unspoken tribute to sisterly love and support; such a notion of sisterly devotion in the face of "hidden maladies" suggests an alternative to the emphasis on self-responsibility demanded by neoliberal models of success and mental wellbeing. Although ultimately not enough, the feelings of responsibility to a collective group are what provides Jude and Elf with the long-term justification to try and stay alive for as long as they do. We know that utopia cannot be born of success: the lessons imparted by failure are vital to the educated hope and militant optimism of the utopian function. Whilst communal support and collective responsibility cannot save Elf and Jude, it is the experiences of those who witness their struggle - who feel that they have failed Elf and Jude-that receive powerful lessons of the importance of empathy and its potentially transformative political resonances.

We know that neoliberalism's modus operandi for its durability is the undermining of collective action and feelings of solidarity. The ramifications of such a prioritizing of individualism in the neoliberal world can arguably be seen in the rise of mental health issues that emphasize feelings of isolation, loneliness, and antisocial withdrawal: depression as the neoliberal condition $d u$ jour. Smail notes that the divorcing of any possible communal empathy and solidarity has led to "Margaret Thatcher's muchcited view that 'There's no such thing as society, only individuals and their families,' find[ing] an unacknowledged echo in almost all approaches to therapy" (Smail 2005: 11). As such, "affective life is forced to bear an increasing burden as the state divests itself of responsibility for social wel- 
fare and affective life is confined to a privatized family" (Cvetkovich 2012: 11). Both $A L L$ and AMPS show the demands placed on familial groups when one of their own becomes suicidal and how 'it takes a village' to keep someone safe and alive. However, the role of community in its demands for life, no matter what the cost, varies significantly across the two novels; it is this difference in approach that I believe is the most significant contribution to reframing suicidal depression in our contemporary moment.

The central tragedy of $A L L$ is arguably not Jude's traumatic past or his inability to miraculously overcome his demons but that his family cannot countenance a life without Jude, so continually pressure him into living longer. At the novel's conclusion, Harold admits that his fear of life without Jude prevented him from truly acknowledging Jude's desperation to be released from his painful inner life:

[I]f he killed himself, if he took himself away from me, I knew I would survive, but I knew as well that survival would be a chore [...]. And of course I knew how badly I would miss him, because although there had been trial runs for his eventual departure, I had never been able to get any better at dealing with them, and I was never able to get used to them. (Yanagihara 2015: 708)

By the novel's end, there is a horrible irony in the number of core familial members who have died too young and before Jude, including Andy, Jude's doctor and confidante. Along with Harold, it is Andy who effectively bullies Jude into a narrative of 'wellness' throughout the novel. And yet Jude, suicidally depressed for most of his life, ends up outliving Andy. Whereas the novel's relentlessly grim and melodramatic tone has been a chief criticism for $A L L$ 's dissenters, I believe that is necessary in order to empathize with Jude: the more over the top and tragic the narrative becomes, the more it becomes impossible to ignore that wanting Jude to continue living is not only wishful fantasy but cruel: "Sometimes he thinks: I can do this. But more and more now, he knows: I can't" (Yanagihara 2015: 664). The novel's conclusion aims to provoke radical empathy in the reader, simultaneously dreading but wishing for Jude's end. After all, Jude's death not only releases him from the relentless narrative but also the reader.

AMPS is more explicit in its radical empathy for the suicidal actor. Towes's narrative shows Yoli's anger shifting focus from her sister's wish to die to the social and legal demands to stay alive. What is different to 
ALL's invocation of empathy is that, in AMPS, it does not matter if the reader disagrees with Elf's wish to die: AMPS is a thorough exploration of Yoli's radical empathy for her family. The final third of Toews's novel is Yoli addressing the now-deceased Elf through her thoughts and via letter. The extent to which Yoli's empathy has developed over the course of the narrative becomes clear when she recounts her turning on a friend who expresses strong views about suicidal actors:

She told me that she's been worrying about me so much, it must be awful, everything I've been going through, and that in her opinion "to die by one's own hand" is always a sin. Always. Because of the suffering it causes the survivors. $[\ldots]$

I said, selfish? How could it be selfish? Unless you've seen the agony firsthand you can't really pass judgment. $[\ldots][\mathrm{H}]$ ow could you understand what another person's suicide means? [...]

I quoted Goethe the way my mother did [...] "suicide is an event of human nature which, whatever may be said and done with respect to it, demands the sympathy of every man, and in every epoch must be discussed anew"... (Toews 2014: 277-278)

In its portrayal of Yoli's developing empathy for her sister's wish to die, AMPS is probably one of the most confrontational yet also nuanced contemporary representations of suicide. Rather than expecting Yoli-and, by extension, the reader - to wholly understand and accept Elf's need to end her life, Toews's choice to focus on a non-suicidal narrative perspective allows the focus to shift from individual responsibility (you need to stay alive for $u s$ ) to the importance of community for the suicidal actor and their loved ones. Yoli cannot prevent her sister from dying, but she can lessen the pain by accepting her sister's absence as desired and, in some ways, necessary for her own life to continue. Rather than torn asunder by grief, Elf's death brings the remaining family closer together:

[Mom] had her arms around me. I pretended she was you [Elf] and dad and $[\ldots]$ all the people I've lost along the way, and then she whispered things to me, all about love, about kindness, and optimism and strength. And about you. About our family.

How we can all fight really hard, but how we can also acknowledge defeat and stop fighting and call a spade a spade. (Toews 2014: 313)

It may seem odd to suggest that suicide can be an act with positive effects, one that strengthens communal feeling. Yet $A L L$ shows how the lack of 
acceptance of absence and resistance of suicidal rationality leads to more individual blame, distress, and guilt. As a protest novel, AMPS concludes on a stronger basis for potential utopian thinking and action: if neoliberal society offers no concrete, meaningful alternative, then something else must be sought in new understandings of what it means to survive, what it means to feel real empathy and solidarity, what alternative ways of being and seeing we can discover through the relationships and connections with one another:

In order to rehabilitate the world, human beings will need to structure their ideals in accordance with the realities of their mutual interdependence. To this end, magic is useless, but utopianism-forms of re-enchantment that depend on human rather than divine effort-is not. (Smail 2005: 107-08; my emphasis)

Neither novel - nor this essay-is thinking through suicide as an abstract exercise in wishful thinking or presenting death as a preferential option to living; utopia is not to be found beyond the veil. The willingness of AMPS and $A L L$ to confront an uncomfortable reality of our contemporary society-the growing awareness of mental anguish and suicidal ideation, if not increase in occurrences - enacts a radical empathy for Elf and Jude. Such a connection is becoming increasingly necessary in a neoliberal world where isolation and disengagement from a wider social body are encouraged by political forces. And yet-radical empathy and social connection have the potential to act as an air bubble injected into the artery: a small, seemingly infinitesimal act whose actions can overwhelm the dysfunctional body. ${ }^{2}$

Acknowledgments I presented my initial ideas at "Fast Forward: Women's Writing in the 21st Century" at Sheffield Hallam, September 2017. My colleague at NTU, Dr. Nicole Thiara, was an enthusiastic and attentive reader of this essay. Many thanks to Nicole and the conference organizers and participants for their generous feedback.

\section{Notes}

1. Although Canada largely escapes the international scrutiny of the UK and the US, recent reports by research think-tanks have focused on the relationship between mental health and employability: Conference Board of Canada 2017: "Improving Youth Mental Health a Priority for Society and the Economy;" Cision Canada (28 November); Mental Health Commission of Canada. 2017: "Commission of Canada Statement on Human Rights Day," 
Cision Canada (8 December) http://www.newswire.ca/news-releases/ mental-health-commission-of-canada-statement-on-human-rightsday-662783083.html, both accessed 17 December 2017.

2. This is the unusual, painful course of action which Jude undertakes to finally succeed in ending his life (Yanagihara 2015: 717).

\section{Works Cited}

Arrighi, Giovanni. 1994. The Long Twentieth Century: Money, Power, and the Origin of Our Times. London/New York: Verso.

Bloch, Ernst. 1986. The Principle of Hope, 3 Vols. Trans. Neville Plaice, Stephen Plaice, and Peter Knight. Oxford: Basil Blackwell.

- 1988. Something's Missing: A Discussion Between Ernst Bloch and Theodor W. Adorno on the Contradictions of Utopian Longing. In The Utopian Function of Art and Literature: Selected Essays, 1-17. Trans. Jack Zipes and Frank Mecklenburg. Cambridge: MIT.

Chang, Ha-Joon. 2014. Economics: The User's Guide. London: Penguin.

Cvetkovich, Ann. 2012. Depression: A Public Feeling. Durham/London: Duke University Press.

Davis, Stevie. 2014. All My Puny Sorrows by Miriam Toews Review-Darkly Fizzing Tragicomedy. The Guardian, July 9. https://www.theguardian.com/ books /2014/jul/09/all-my-puny-sorrows-miriam-toews-review-darklyfizzing-tragicomedy. Date accessed 17 December 2017.

Gilbert, Jeremy. 2013. What Kind of Thing Is 'Neoliberalism'? New Formations 80/81: 7-22.

Gilroy, Paul. 2013. We Got to Get Over Before We Go Under': Fragments for a History of Black Vernacular Neoliberalism. New Formations 80/81: 23-38.

Goodley, Dan. 2001. 'Learning Difficulties', the Social Model of Disability and Impairment: Challenging epistemologies', Disability \& Society, 16 (2): 207-231.

Halberstam, Jack. 2011. The Queer Art of Failure. Durham: Duke University Press.

Harvey, Harvey. 1989. The Condition of Postmodernity: An Enquiry into the Origins of Cultural Change. Oxford: Blackwell.

James, Oliver. 2007. Affluenza: How to Be Successful and Stay Sane. Reading: Vermilion.

- 2008. The Selfish Capitalist: Origins of Affluenza. Reading: Vermilion.

Karp, David A. 2001. The Burden of Sympathy: How Families Cope with Mental Illness. Oxford: Oxford University Press.

Klein, Elise. 2017. Developing Minds: Psychology, Neoliberalism and Power. New York: Routledge. 
Levitas, Ruth. 1990. Educated Hope: Ernst Bloch on Abstract and Concrete Utopia. Utopian Studies 1 (2): 13-26.

Mills, China. 2014. Decolonizing Global Mental Health: The Psychiatrization of the Majority World. New York: Routledge.

O'Keefe, Alice. 2015. Miriam Toews: 'I Worried People Would Think, What Is Wrong with This Family?'. The Guardian, May 2. https://www.theguardian. $\mathrm{com} /$ books $/ 2015 / \mathrm{may} / 02 /$ miriam-toews-interview-all-my-puny-sorrowsmennonite. Date Accessed 17 Dec 2017.

Preston, Alex. 2015. A Little Life by Hanya Yanagihara Review-Relentless Suffering. The Guardian, August 18. https://www.theguardian.com/books/ 2015/aug/18/a-little-life-hanya-yanagihara-review-man-booker-prize. Date Accessed 17 Dec 2017.

Raphelson, Samantha. 2017. How the Loss of U.S. Psychiatric Hospitals Led to a Mental Health Crisis. NPR, November 30. https://www.npr. org $/ 2017 / 11 / 30 / 567477160 /$ how-the-loss-of-u-s-psychiatric-hospitalsled-to-a-mental-health-crisis. Date Accessed 17 Dec 2017.

Smail, David. 2005. Power, Interest and Psychology: Elements of a Social Materialist Understanding of Distress. Monmouth: PCCS Books.

Stone, Jon. 2017. Theresa May Pledges to Tackle 'Stigma' of Mental Health but Dismisses Call for Extra Funding. The Independent, January 9. http://www. independent.co.uk/news/uk/politics/theresa-may-mental-health-stigmafunding-government-nhs-a7516461.html. Date Accessed 17 Dec 2017.

Toews, Miriam. 2014. All My Puny Sorrows. London: Faber \& Faber. Kindle Edition.

Yanagihara, Hanya. 2015. A Little Life. London: Picador. Kindle Edition. 